\title{
Dinamika Peran Ngo Lingkungan Hidup Dalam Arena Politik Lokal Di Provinsi Jambi
}

\author{
Moh. Arief Rakhman ${ }^{1}$, Haryadi ${ }^{2}$ \\ ${ }^{1}$ Prodi Ilmu Politik, Universitas Jambi, Indonesia \\ ${ }^{2}$ Fakultas Hukum, Universitas Jambi, Indonesia \\ Email: moh.ariefrakhman@unja.ac.id
}

\begin{abstract}
Abstrak: Penelitian ini dilatarbelakangi oleh adanya fenomena yang ditunjukkan oleh NGO lingkungan hidup yang bergerak dalam bidang lingkungan hidup, dimana untuk provinsi Jambi mempunyai jumlah sebaran yang tidak bisa dibilang sedikit. NGO lingkungan hidup yang ada di Jambi beroperasi dalam berbagai jaringan, mulai dari lokal,nasional sampai yang berskala internasional. Bentuk,sifat dan kekuatan masing-masing jaringan tersebut menentukan masa depan keberlanjutan sektor NGO Lingkungan hidup di Jambi maupun Indonesia secara lebih luas. Penelitian ini menjelaskan fungsi NGO Lingkungan hidup sebagai kekuatan kekuatan politik yang muncul dan mampu memberikan pengaruh kuat terhadap proses pembuatan kebijakan di ranah pemerintahan lokal. Penelitian menganut paradigma konstruktivisme dengan menggunakan pendekatan kualitatif untuk memberikan penjelasan dan memahami peristiwa yang sedang atau telah terjadi, yang menekankan pada interpretasi makna kategori yang berkembang dari informan penelitian. Hasil dari penelitian ini diharapkan pemahaman bagaimana strategi dan pencapaian NGO lingkungan hidup di Jambi dalam memberikan terhadap kebijakan-kebijakan terkait lingkungan.
\end{abstract}

Kata Kunci : NGO, Kekuatan Politik, Kebjakan, Lingkungan hidup

Abstract: This research is motivated by the existence of a phenomenon shown by environmental NGOs engaged in the environmental sector, where Jambi province has an indefinitely small amount of distribution. Environmental NGOs in Jambi operate in various networks, ranging from local, national to international ones. The form, nature and strength of each of these networks determine the future sustainability of the NGO Environment sector in Jambi and Indonesia more broadly. This research explains the function of environmental NGOs as an emerging political force capable of exerting a strong influence on the policy-making process in the realm of local government. Research adopts a constructivist paradigm by using a qualitative approach to provide an explanation and understanding of events that are or have occurred, which emphasizes the interpretation of the meaning of the developing categories of the research informants. The results of this research are expected to understand how the strategies and achievements of environmental NGOs in Jambi in providing environmental related policies.

Keywords: NGO, Political Power, Policy, Environment

\section{PENDAHULUAN}

Ngo (Non Government Organization) adalah istilah yang digunakan untuk menyebut suatu lembaga, kelompok, atau organisasi yang aktif mengupayakan pemberdayaan masyarakat dan pembangunan, terutama pada lapisan masyarakat bawah, dikenal istilah Non-Goverment Organization (NGO). Istilah ini umum dipakai oleh organisasi-organisasi yang bernaung di bawah
Perserikatan Bangsa-bangsa (PBB). Dalam suatu konferensi yang diadakan oleh Wahana Lingkungan Hidup Indonesia (WALHI) pada 1976, istilah NGO kemudian diterjemahkan ke dalam bahasa Indonesia menjadi Organisasi Non-Pemerintah (ORNOP) atau istilah yang kemudian popular belakangan ini juga disebut sebagai CSO (Civil Society Organizations) (Mansour: 2003). 
Ditingkat Nasional sendiri, Istilah NGO, atau LSM mulai diusulkan oleh Sakiran Mangunpranoto pada pertemuan antar organisasi non pemerintah yang bergerak di bidang pembangunan perdesaan di Ungaran, Jawa Tengah tahun 1978. Nama pertama yaitu Lembaga Pembina Swadaya Masyarakat, kemudian dirubah menjadi LSM. Dalam UU No 8 Tahun 1985 tentang Organisasi Kemasyarakatan, tidak mengatur batasan LSM. Baru kemudian pada Instruksi Menteri Dalam Negeri No 8 Tahun 1990 tentang Pembinaan Lembaga Swadaya Masyarakat, dirinci tentang pengertian LSM (Purwanto:2012). Di tingkat Internasional adalah Organisasi Non Pemerintah (ORNOP) yang merupakan terjemahan dari Non Governmental Organization (NGO) seperti yang dituangkan di paragraph pertama.

Pasal 1 ayat (12) UU No 4 Tahun 1982 tentang Ketentuan Pokok-pokok Lingkungan Hidup, dan kemudian sesuai dengan Undang-Undang Nomor 17 Tahun 2013, tentang Ormas, yang memberikan defenisi kepada Organisasi Kemasyarakatan (Ormas) sebagai, organisasi yang didirikan dan dibentuk oleh masyarakat secara sukarela berdasarkan kesamaan aspirasi, kehendak, kebutuhan, kepentingan, kegiatan, dan tujuan untuk berpartisipasi dalam pembangunan demi tercapainya tujuan Negara Kesatuan Republik Indonesia yang berdasarkan Pancasila (Lihat UU Ormas: Pasal 1)). penjelasannya mendefinisikan Ormas adalah organisasi yang tumbuh secara swadaya, atas kehendak dan keinginan sendiri di tengah masyarakat dan berminat serta bergerak di bidang lingkungan hidup. Pada intinya Ormas termasuk bagian dari kelompok masyarakat. Untuk aturan dalam UU No 23 Tahun 1997 tentang Pengelolaan Lingkungan Hidup, dan UU No 32 Tahun 2009 tentang Perlindungan dan Pengelolaan Lingkungan Hidup, tidak dijelaskan batasan istilah ini. selanjutnya sebutan Ormas, bisa juga disebut dengan NGO, LSM atau pun Ornop dalam laporan kemajuan ini.

Setelah Bulan November 2001, atau tiga tahun pasca Reformasi, Majelis Permusyawaratan Rakyat (MPR) mengeluarkan Ketetapan melalui TAP MPR
Nomor IX/2001 Tentang Pembaruan Agraria dan Pengelolaan Sumber Daya Alam (PA dan PSDA). Dimana ketetapan ini adalah adalah bukti unjuk partisipasi demokratis dari masyarakat sipil dalam pembentukan perundang-undangan, yang juga merupakan tonggak dimana Gerakan agrarian dan Gerakan yang mana didalamnya terdapat banyak NGO yang memiliki concern terhadap hal tersebut bersinergi dalam memanfaatkan kesempatan politik yang terbuka pasca rezim otoritarian tumbang.

Selanjutnya Pasal 92 UU No 32 Tahun 2009 tentang Perlindungan dan Pengelolaan Lingkungan Hidup, mengatur hak gugat organisasai lingkungan hidup, dalam rangka pelaksanaan tanggung jawab perlindungan dan pengelolaan lingkungan hidup, organisasi lingkungan hidup berhak mengajukan gugatan untuk kepentingan pelestarian fungsi lingkungan hidup. Hak inilah yang kemudian menjadi salah satu sebab dikemudian hari Banyak penelitian yang menemukan hasil bahwa NGO mempunyai kemampuan untuk melakukan pemanfaatan atas berbagai keluhan yang dilakukan secara kolektif, NGO juga dipercaya dapat membangun struktur kesempatan politik yang dapat membentuk mobilisasi, framing dan berbagai bentuk aksi.

Dengan semakin berkembangnya politik dan budaya demokrasi yang lebih standar di Indonesia, rakyat indonesia menjadi lebih butuh saluran agar bisa menyuarakan aspirasi \& idealismenya terkait penghidupan yang baik. Sebelumnya peran tersebut di dominasi oleh Partai Politik. Seiring dengan berkembangnya demokrasi di negeri ini peranan partai-partai tersebut sedikit demi sedikit berevolusi dari organisasi politik massa menjadi hanya alat bagi para politisi untuk tetap berkontestasi dalam arena untuk berebut kekuasaan. Menurut Civil Society Engagement Framework milik DFAT, Non Government organizations (NGO) adalah produk dari civil society, dengan fungsi`sebagai lembaga non-pemerintah dan non-pasar yang mana sekelompok masyarakat dapat secara mandiri melakukan pengorganisiran guna mencapai tujuan atau nilai-nilai bersama dalam kehidupan (CSEF: 2012). 
Organisasi masyarakat sipil (Ormas) selanjutnya akan kita sebut NGO, adalah ruang dimana masyarakat mampu mengimbangi kuasa negara bersama pasar lewat cara yang beragam, seperti melakukan advokasi keadilan sosial dan ekonomi, dan dengan melakukan pemenuhan kebutuhan pembangunan sosial yang belum bisa dijawab atau dilakukan oleh negara dan pasar. Biasanya menjadi anggota dalam organisasi masyarakat sipil mempunyai prinsip kesukarelaan dan mandiri, serta terdapat kebiaasaan jika muncul keuntungan yang didapatkan, maka keuntungan itu dikembalikan ke dalam organisasi daripada menjadi keuntungan per individu. Dalam kerangka kerja operasional, organisasi masyarakat sipil termasuk juga di dalamnya adalah organisasi berbasis masyarakat, yang melakukan pekerjaannya di tingkat lokal dan tergantung kepada kontribusi dari para anggota yang lain agar bisa operasional, tidak jarang untuk kepentingan para anggotanya sendiri.

Melalui NGO (Non-Government Organization), masyarakat mempunyai wadah untuk melakukan advokasi dan memperjuangkan isu-isu yang bagi mereka adalah isu penting. Dengan kondisi dimana sangat banyak persoalan sosial yang menghampiri masyarakat, maka tidak aneh jika NGO di negara-negara berkembang dan demokratis, organisasi seperti tumbuh menjadi sangat banyak. Banyak penelitian yang menemukan hasil bahwa NGO mempunyai kemampuan untuk melakukan pemanfaatan atas berbagai keluhan yang dilakukan secara kolektif, NGO juga dipercaya dapat membangun struktur kesempatan politik yang dapat membentuk mobilisasi, framing dan berbagai bentuk aksi. Bagaimana NGO melakukan manuver politiknya, NGO mewujudkan dgn cara memberikan pengaruh langsung kepada otoritas yang menjadi kunci, melakukan peningkatan eskalasi berbentuk pressure politik kepada pihak otoritas atau pemerintah, lewat pemakaian jejaring advokasi antar negara, memberikan dorongan terhadap keberlanjutan pasar, memberikan tekanana terhadap masuknya modal, memobilisasi persepsi sehingga memunculkan dukungan dari para elit dan mengangkat ide atau inovasi baru yang lengkap dengan berbagai praktik ideal sebagai sebuah alternatif solusi tandingan. Salah satu arena yang menjadi perhatian besar dari NGO adalah arena politik lingkungan hidup. Arena politik lingkungan hidup dalam hal ini mengacu pada pendapat Princen dan Finger dalam karyanya (Finger: 1994), yang memberikan Batasan tentang arena politik lingkungan hidup, diperkuat oleh Neil Carter yang menyatakan bahwa, arena Politik Lingkungan hidup, mencakup kebijakan, tata kelola dan praktek-praktek pengelolaan lingkungan hidup (Carter:2007).

Provinsi Jambi sebagai sebuah Provinsi yang mengandalkan pertumbuhan ekonominya pada aktifitas eksploitasi sumber daya alam sebagai basis dalam rangka penyediaan bahan baku. Hal ini diperkuat dengan melihat berbagai produk kebijakan yang dihasilkan, Provinsi Jambi melalui agenda "Jambi Tuntas" sebagai judul besar dalam pelaksanaan visi dan misi pemerintahan, menargetkan pertumbuhan ekonomi $6,65 \%$. Dengan melihat dokumen PERDA No 7 Tahun 2016 tentang RPJMD Provinsi Jambi 2016-2021 yang kini telah mengalami perubahan dan sebagai satu dokumen penerjemah Jambi Tuntas, pertumbuhan yang ditargetkan tersebut masih bersumber pada sektor penopang utamanya, yaitu pertambangan dan industri pengolahan juga perdagangan jika dilihat sampai tahun 2016 tidak memiliki banyak perbedaan signifikan. Atau setidaknya samapai 2021, skenario kebijakan dalam perencanaan pembangunan yang disusun, juga tidak jauh berbeda, tetap bersandar pada sumber-sumber alam yang akan tereksploitasi, terutama sumber-sumber pertambangan, industri perkebunan monokultur dan HTI.

Kebijakan seperti ini, terlepas dari sisi kemampuannya untuk mempercepat laju pertumbuhan ekonomi namu seperti dibanyak provinsi lain di Indonesia, rawan menyebabkan berbagai masalah yang berpotensi menyulut berbagai konflik, data dari Wahana Lingkungan Hidup Indonesia (WALHI), berbagai permasalahan potensial akan timbul dari beberapa sector yang 
berhubungan dengan pengelolaan sumberdaya alam di Jambi, Kebijakan pembangunan industry kelapa sawit, HTI, Pertambangan, Perlindungan serta Pengelolaan Gambut, masalah Perhutanan Sosial dan Tanah obyek reforma agrarian (TORA), adalah masalah masalah yang banyak dan masih akan bermunculan di Provinsi ini. Hal yang sama juga di munculkan oleh NGO lainya yang punya base area di provinsi ini, seperti Komunitas Konservasi Indonesia -warung Informasi KOnservasi (KKI-Warsi), sebuah NGO yang banyak berkegiatan dalam pendampingan masyarakat di dalam dan disekitar hutan di Dengan kondisi seperti dipaparkan sebelumnya, keadaan tersebut membuat Provinsi Jambi masuk kedalam kondisi dimana potensi kerusakan lingkungan, distribusi penguasaan tanah dan sumberdaya alam yang timpang, dan rawan konflik agraria, sangat mudah terjadi. maka tidak heran berbagai NGO yang mempunyai Concern, minat tersendiri dalam pengelolaan dan pemeliharaan lingkungan hidup, pengembangan dan pemberdayaan masyarakat bermunculan di Provinsi Jambi.

Arena Politik lingkungan hidup mendapat perhatian besar dari NGO, baik nasional maupun internasional. NGO mempunyai peran sentral dan strategi penting dalam kancah politik lingkungan hidup, bukan hanya ditingkat global, ditingkat nasional pun pengaruhnya tidak bisa diabaikan begitu saja (David: 2016). kancah politik lingkungan hidup yang dimaksud adalah merujuk kepada Princen, Finger \& Carter, termasuk didalamnya policy, tata kelola \& praktik-praktik tata kelola lingkungan hidup. didalam penelitian ini politik lingkungan hidup diberikan batas anya di beberapa kasus lingkungan \& agrarian yang terjadi di Provinsi Jambi. hal yg sama yang muncul dalam data

Beberapa penelitian terdahulu menunjukan bahwa NGO sektor lingkungan hidup di Indonesia bisa berperan sebagai organisasi sosial yang bertujuan mempercepat terciptanya hubungan kuasa pada multi actor yang ada, hal ini dilakukan melalui cara memberikan pengaruh terhadap kebijakan yang dibuat, hukum, pasar juga sector swasta, serta memasyarakatkan ide-ide baru yang berbasiskan masyarakat pada ditingkat lokal, bertujuan menciptakan penguatan tata kelola sumberdaya alam yang baik di negeri ini. misalnya dalam penelitian kausar, yang dimuat di Indonesian Journal of Agricultural Economics (IJAE), yang berjudul Konflik kepentingan dibalik konservasi studi di taman nasional Kerinci Seblat(TNKS) Provinsi Jambi, dipaparkan bahwa konflik kepentingan antara masyarakat lokal dan pemerintah Daerah dimana NGO di posisikan dalam posisi yang di curigai sebagai perpanjang tangan negara maju dalam membawa isu konservasi ke daerah yang berujung motif bisnis, namun keberadaan meraka juga dinilai sebagai bagian dari solusi, untuk kasus TNKS, pemahaman terhadap konsep Community based management, yang terlihat lebih dipahami oleh NGO menjadi sebuah resolusi konflik pada saat itu (IJAE: 2010).

$$
\text { Penelitian selanjutnya juga }
$$

menunjukan bagaimana peran NGO lingkungan hidup dalam turut serta memberi tekanan terhadap pemerintah yang secara tidak langsung menunjukan kekuatan politiknya sebagai salah satu elemen civil society yang ada di provinsi Jambi sering muncul dibeberapa moment karhutla yang kerap terjadi di Provinsi ini, sebagai mana hasil penelitian dari David, Adiwibowo, dan Ekawati, yang memaparkan bagaimana peran dan strategi yang di lakukan NGO terhadap pemerintah kerapkali terbukti effektif memberikan tekanan yang kemudian memunculkan kebijakan public yang tepat sasaran. Dalam artikelnya yang berjudul NGO's Roles and Strategies in the Environmental Politic Arena, mereka menemukan bahwa, Strategi politik NGO lingkungan hidup dalam beberapa kasus Karhutla adalah mempengaruhi langsung sasaran perubahan, menggunakan jaringan advokasi transnasional, mempengaruhi aliran kapital, memanfaatkan dukungan elit pemerintahan, serta mempromosikan praktikpraktik terbaik pada tingkat lokal. Upaya tersebut memberikan pengaruh dalam bentuk lahirnya regulasi, memperkuat upaya penegakan hukum, mempengaruhi perilaku sektor swasta serta mendorong tumbuhnya 
praktik-praktik lokal dalam pengelolaan lahan gambut berbasis masyarakat, dan ini dilakukan juga di Jambi (David: 2016).

\section{METODE PENELITIAN}

Penelitian ini menganut paradigma konstruktivisme dan memakai pendekatan kualitatif agar bisa memunculkan penjelasan dan pemahaman terkait peristiwa terjadi saat ini maupun telah lampau, yang memberikan penekanan pada interpretasi makna yang berkembang dari informan penelitian (Denzin: 2009). Metode kualitatif adalah cara meneliti yang bisa memunculkan data deskriptif berbentuk kalimat tertulis maupun lisan. Cara melakukan proses mengumpulkan data adalah melalui indepth interview dan studi Pustaka, mempelajari dokumen-dokumen terkait. Untuk memilih informan dipakailah metode bola salju, Klasifikasi informan adalah aktivis NGO yg menjabat sebagai pimpinan di organisasinya, akademisi, wartawan, perwakilan pejabat pemerintah yang memiliki pengetahuan dan informasi terhadap beberapa kasus terkait NGO lingkungan hidup yang ada di Jambi. terkait dengan waktu yang bertepatan dengan kemunculan Pandemi Covid 19 sehingga muncul keterbatasan mobilitas untuk melakukan penelitian di lapangan, maka penelitian ini akan lebih menitik beratkan kepada studi Pustaka.

\section{TINJAUAN PUSTAKA}

\section{Ekologi Politik}

Ekologi politik adalah perpaduan perhatian kepada lingkungan dan juga politik ekonomi secara umum, yaitu discourse diantara masyarakat dengan sumberdaya berbasis lahan, termasuk dalamnya dialektika kelas dan kelompok2 di masyarakat. Bryant dan Bailey, memberikan penambahan penjelasan, bahwa ekologi politik adalah studi tentang SDA, keadaan \& implikasi politik yang berasal dari rusaknya alam, dimana dalam kaitannya dengan negara berkembang krisis lingkungan tersebut lebih banyak berawal pada timpangnya relasi kuasa (Bryan: 1997).

Ekologi politik mulai berkembang sejak akhir tahun 1970an dan awal 1980an. Istilah ekologi politik pertama kali dicetuskan oleh Russet (1967), Eric Wolf (1972), Miller (1978), Corckburn dan Ridgeway (1970). Banyak bidang-bidang dalam kehidupan manusia yang berkaitan erat dengan ekologi politik seperti cultural ecology, human ecology, ecological anthropology, ecological economics, radical development geography dan environmental history. Terkadang ekologi politik disamakan dengan politik lingkungan (environmental politics). Namun ekologi politik dan politik lingkungan mempunyai perbedaan pada dasar konsepnya. Politik lingkungan adalah bidang studi pada ilmu politik terkait masalah lingkungan. Contohnya meneliti apa yang disebabkan oleh isu lingkungan kepada prosesi politik umum serta posisi pemerintah terkait pengelolaan lingkungan. Dalam politik lingkungan ada anggapan berperspektif teknosentrik daripada ekosentrik, jadi memunculkan kesimpulan kaitannya dengan ekologi politik tidak terlalu kuat (Rachman: 2005).

Terdapat dua pendekatan yang ada pada ekologi politik menurut Bryant \& Bailey yaitu pendekatan aktor dan pendekatan kritis. Pendekatan aktor berpusat pada pelaku (Actor Oriented-AO). Lima aktor yang sebutkan oleh Bryan dan Bailey yaitu negara, pengusaha, lembaga multilateral, NGO dan aktor pengguna maupun pelindung sumber daya alam. Pendekatan kritis didasarkan pada teori kritis yang dikembangkan sejak Tradisi Frankfurt (Rachman: 2005).

Seiring dengan tingkat sadarnya masyarakat terhadap berbahayanya perusakan lingkungan hidup yg semakin membaik khususnya di negara-negara berkembang, maka praktik-praktik eksploitasi terhadap sumber daya alam (natural resources) yg mengancam ekosistem mulai mendapat perlawanan dari berbagai elemen masyarakat. Mereka bersatu dalam berbagai NGO dan melakukan berbagai aktivitas gerakan lingkungan, yaitu gerakan yang bertujuan untuk meningkatkan kesadaran masyarakat terhadap pelestarian lingkungan hidup serta bahaya yang diakibatkan oleh perusakan lingkungan. Bahkan mereka juga melakukan resistensi terhadap berbagai pihak baik pemerintah maupun swasta yang baik langsung atau tidak langsung berkontribusi 
akan terjadinya kerusakan lingkungan hidup. Satu hal yang menarik adalah bahwa organisasi dan gerakan lingkungan ini bukan semata-mata organisasi yang bersifat lokal, tetapi mereka sering kali memiliki jaringan yang bersifat nasional bahkan internasional. Fenomena penguatan sektor ketiga ini (civil society organization (CSO)/civil society association (CSA), NGO) merupakan kekuatan gerakan sosial baru yang menguat sejak dirasakan gejala deep distrust terhadap organisasi politik konvensional seperti negara, birokrasi dan lembaga perwakilan rakyat (Dharmawan: 2005).

\section{NGO Lingkungan Hidup}

Menurut definisnya, NGO atau LSM adalah organisasi yang dibentuk suatu kelompok dan bersifat mandiri, tidak tergantung kepada pemerintah utamanya terkait pendanaan dan sarana atau prasarana. Organisasi berdiri atas komitmen warga negara yang peduli terhadap isu-isu yang muncul dari berbagai sektor dalam kehidupan berwarganegara, dari sosial, ekonomi hingga politik (Afan Gaffar: 2006). Ditingkat Internasional, NGO sendiri secara umum dikenal dengan penggolongan kepada dua jenis. NGO yang berorientasi kepada aksi atau Program dan yang lainnya adalah NGO yang berfungsi sebagai Lembaga-lembaga donor. Jenis NGO Aksi dan program, adalah mereka yang menjalankan programnyaa karena keresahan atau keprihatinan terhadap berbagai masalah yang muncul di masyarakat, NGO Lingkungan hidup masuk kedalam penggolongan jenis ini. sedangkan untuk jenis selanjutnya, adalah NGO yang memfungsikan lembaganya sebagai Lembaga donor yang mengkhususkan pada penyaluran bantuan kepada NGO-NGO di jenis pertama yang daerah operasional nya dikenal sebagai "Dunia ke-3", yang dilakukan NGO Jenis ini memang lebih banyak bergerak dalam penghimpunan dana dari usaha-usaha swadaya masyarakat, sumbangan Pilantropis, donator perusahaan, atau tidak jarang juga mengumpulkan dana yang berasal dari bantuan Kerjasama Internasional. Selanjutnya NGO Kemudian mulai menapat pengakuan Nasional, Regional, maupun Internasional.
Perkembangan NGO di kancah politik lingkungan hidup bisa dipandang sebagai proses demokratisasi di sektor lingkungan hidup yang sedang berproses (Princen: 1994). Berawal dari Konferensi Bumi yg di adakan di Brazil pada tahun 1992, ke aktifan berbagai NGO sektor lingkungan hidup mengalami perkembangan yang sangat baik. Berubahnya berbagai kebijakan terkait pengelolaan lingkungan hidup tidak lagi terpusat kepada aktoraktor Negaraa, tapi juga organisasi-organisasi civil society, turut serta sebagai wakil aktor bukan-negara (Guadalope: 2004).

NGO bisa memiliki peran sinifikan dalam diplomasi lingkungan hidup, membesarkan jejaringan advokasi lintas negara dalam konteks berhadapan dengan masalah lingkungan hidup dan memberi pengaruh terhadap standar keberlanjutan lingkungan. singkatnya, NGO lingkungan hidup adalah salah satu aktor yang diakui posisinya dalam politik lingkungan global. NGO memiliki peran dan strategi dalam rangka mendukung keseimbangan hubungan kuasaantara pemerintah, swasta dan rakyat. NGO merupakan salah satu elemen dalam gerakan sosial (Fakih: 1996). Pengertian NGO dalam penelitian ini mengacu pada definsi bahwa, NGO adalah organisasi private, non komersil dan proffesional dilengkapu dengan masalah legal kelembagaan secara hokum yang jelas, mempunyai kepedulian terhadap berbagai tujuan yang bermuara pada Kesejahteraan.

NGO adalah organisasi gerakan sosial profesional yang mempunyai ke khasan, adanya nilai profesionalisme, sistem manajemen \& struktur organisasi yg formal dan skill teknis spesifik yang digunakan untuk keperluan gerakan (Diani: 2006). Kemunculan NGO lingkungan hidup, muncul saat isu tentang lingkungan telah menjadi wacana global,di samping isu hak asasi manusia dan isu gender. Berawal dari isu sederhana tentang pelestarian alam demi tujuan rekreasionaI,isu lingkungan kemudian bergulir, berproses,dan melembaga sebagai erakan yang banyak dilakukan oleh NGO lingkungan. Dalam perkembangannya, NGO lingkungan memang lebih tampak sebagai 
agen utama da1am gerakan lingkungan,yang dinamikanya dicerminkan pada munculnya berbagai ragam NGO lingkungan. Sebagaimana yang diungkapkan muhamad budairi, Defenisi dari LSM/NGO, secara sederhana bisa diartikan sebagai Gerakan yang tumbuh berdasarkan nilai-nilai kerakyatan, dengan tujuannya adalah untuk menumbuhkan kesadaran dan kemandirian masyarakat, dengan akhir yaitu menciptakan kesejahteraan rakyat. Oleh karena itu, di suatu negara dengan sistem yang Demokratis, NGO pun secara alamiah menjadi salah satu kelompok yang mempunyai kekuatan politik yang bersumber dari Rakyat.

\section{Gerakan Sosial Baru}

Untuk menganalisis peran dan strategi NGO lingkungan dalam ranah politik sehingga mempengaruhi kebijakan-kebijakan Pemerintah Daerah Provinsi Jambi, maka studi ini berpijak pada kerangka teori Gerakan Sosial Baru (GSB). Menurut Singh teori GSB merupakan penjelasan terhadap pergeseran gerakan sosial dari isu redistributif menuju kualitas hidup (Singh: 2001). GSB berkembang sebagai kritik dari teori-teori gerakan sosial lama yang didominasi oleh kerangka pemikiran Marxian, yang memfokuskan pada konsep perjuangan kelas dengan kaum buruh sebagai pusat perubahan sosial. Gerakan sosial lama dianggap tidak lagi memadai untuk menjelaskan perkembangan gerakan sosial yang memasuki konflik-konflik baru seperti konflik identitas, nilai-nilai dan kultural yang tidak bisa direduksi sebagai konflik proses produksi (Saunders: 2013). Saunders menjelaskan bahwa GSB memiliki karakteristik anti modernisasi, tidak berbasis kelas tertentu dalam masyarakat, tampil dalam bentuk yang partisipatif, tidak hirarkis dan terdesentralisasi, dengan orientasi pada kebebasan dan otonomi masyarakat sipil. Salah satu bentuk Gerakan Sosial baru ini adalah gerakan lingkungan hidup.

Penelitian ini melihat bahwa perkembangan NGO Lingkungan hidup sebagai organisasi gerakan lingkungan hidup dilihat dari lensa analisis Gerakan social baru. Dalam konteks Indonesia, maupun Pengelolaan di daerah seperti Provinsi Jambi. tepat Ketika situmorang, mengembangkan sintesis dari konsep-konsep teori gerakan sosial untuk menganalisis dinamika proses kolektif lingkungan hidup. Konsep-konsep tersebut adalah keluhan kolektif, struktur kesempatan politik, struktur mobilisasi, proses framing dan bentuk-bentuk aksi (Situmorang: 2013). Mc Adam et al, menjelaskan hubungan konsep-konsep tersebut diatas sebagai alat analisis dalam melihat gerakan sosial kontemporer secara empiris (Adam: 1997). Keluhan kolektif adalah bentuk ketidakpuasan terhadap ketidakadilan yang dirasakan atau diterima masyarakat luas, meskipun bukan satusatunya yang mendorong terjadinya protes. Struktur kesempatan politik adalah tandatanda yang konsisten pada tatanan politik yang memberi peluang pada aktor politik untuk membentuk sebuah gerakan sosial. Keluhan kolektif dan struktur kesempatan politik memungkinkan organisasi gerakan sosial.

\section{HASIL DAN PEMBAHASAN HASIL}

\section{Kondisi Kerusakan Lingkungan Hidup di Provinsi Jambi}

Narasi mengenai lingkungan hidup dan eksploitasi sumber daya alam yang berlebihan merupakan bukan hal yang baru di tingkat global, nasional, maupun local. isu ini telah berkembang menjadi awal dari berbagai perubahan relasi antara beberapa pihak, negara, masyarakat, Swasta. Seperti kebanyakan permasalahan lingkungan yang terjadi di Indonesia pada umumnya, apa yang menjadi permasalahan lingkungan di Provinsi Jambi tidak jauh berbeda, akar masalah selalu terkait dengan masalah kebijakan dan kepentingan ekspansi industri berbasis hutan lahan juga pertambnagan, hal yang sudah dimulai sejak Gelombang pertama pembukaan hutan secara luas adalah sejak tahun 1970-an, dimana pemerintah memberikan izin secara besar-besaran kepada perusahaan kayu dalam skema Hak Pengusahaan Hutan (HPH) dan Hutan Tanaman Industri (HTI). Gelombang kedua adalah ekspansi perkebunan kelapa sawit 
sejak tahun 1990-an di Pulau Sumatra dan Kalimantan.

Pada masa ini juga ditandai dengan proyek pembukaan lahan gambut sejuta hektar di Kalimantan Tengah pada periode 1995-1999 untuk kepentingan pertanian. Gelombang ketiga adalah terjadinya peningkatan permintaan produk kelapa sawit pada pasar global sejak tahun 2000, dimana kelapa sawit menjadi primadona ekspor untuk perolehan devisa negara. Indonesia tercatat sebagai produsen kelapa sawit global terbesar di dunia bersama dengan Malaysia.

Jambi adalah salah satu provinsi di Indonesia yang berada di pulau Sumatera dengan jumlah penduduk sekitar 3,4 juta jiwa. Luas wilayah kurang lebih 5 juta hektar dimana kurang lebih 2,1 juta hektar berupa hutan dan, Berdasarkan Rencana Tata Ruang Wilayah Provinsi Jambi (Rt/Rw), Peraturan daerah No. 10 Tahun 2013, luas Provinsi Jambi $53.435 \mathrm{Km} 2$. dengan Luas kawasan hutan Provinsi Jambi berdasarkan SK Menhut No : 863/Menhut-II/2014 adalah 2.098.535 $\mathrm{Ha}$ atau $42,98 \%$ dari luas daratan seluas 4.882.857 Ha dan termasuk di dalamnya 0,6 juta hektar adalah lahan gambut dari luasan tersebut, sampai saat ini beberapa konflik masih terjadi hampir merata di wilayah Provinsi Jambi. Oleh karena itu diperlukan formulasi-formulasi untuk bisa menyelesaikan konflik di dalam kawasan hutan agar kawasan hutan bisa dimanfaatkan secara kolaboratif (Cappa Index: 2020).

Analisa citra satelit Lansat TM 8 yang dilakukan oleh Unit GIS Komunitas Konservasi Indonesia (KKI) Warsi menunjukkan tutupan hutan Jambi tinggal 900 ribu hektare atau 17 persen dari 50.160 kilometer persegi luas wilayah Provinsi Jambi pada 2019. Berkurangnya luasan tutupan hutan di Provinsi Jambi tersebut disebabkan oleh beberapa faktor. Di antaranya aktivitas illegal drilling, aktivitas Penambangan Emas Tanpa izin (PETI), dan Kebakaran Hutan dan Lahan (Karhutla) yang marak terjadi dalam beberapa tahun terakhir (Tempo: 2019).

Dari sebelas kabupaten dan kota di Provinsi Jambi, kabupaten yang luasan tutupan hutannya paling banyak berkurang terjadi di kabupaten dengan kawasan hutan yang masih banyak, diantaranya di Kabupaten Tebo, Merangin dan Muaro Bungo. Namun kebakaran lahan gambut turut menyebakan luasan tutupan hutan dijambi berkurang secara signifikan. Semua kejahatan ekosistem yang akan dan telah merusak lingkungan tersebut menyebabkan dampak yang cukup luas, mulai dari bencana ekologis, konflik satwa, konflik lahan dan kerugian yang sangat besar terhadap lingkungan.

Berbagai permasalahan-permasalahan yang bersumber pada Sumber daya alam dan lingkungan selain timbul karena pasca reformasi mengendurnya kontrol pusat sebagai akibat desentralisasi telah mendorong munculnya potensi maupun konflik terkait dengan kekayaan alam yang ada. Secara makro, pendapatan dari sektor ekstraktif tersebut memang unggulan berkontribusi bagi stabilitas angka-angka di deretan kolom APBD Provinsi Jambi, tapi secara mikro, kekayaan alam tersebut tersebut ibarat racun bagi masyarakat lokal yang tinggal di sekitar wilayah wilayah yang seharusnya pemerintah setempat mampu mentransformasikan kekayaan alam itu menjadi kesejahteraan masyarakat. Di Provinsi Jambi, lokasi-lokasi seperti inilah kemudian, NGO atau seringkali disebut, LSM (Lembaga Swadaya Masyarakat), atau PVO (Private Voluntary Organization), atau CSO (Civil Society Organization) atau pernah juga popular dengan sebutan Ornop (Organisasi NonPemerintah) yang bergerak dalam bidang lingkungan hidup beroperasi, mendekat dengan Rakyat, mendapat kepercayaan, dan secara politik, perlahan mengumpulkan kekuatan.

\section{NGO Lingkungan Hidup di Provinsi Jambi}

Pembentukan jaringan NGO (Non Government Organization) atau LSM di Provinsi Jambi dimulai dengan dua organisasi kunci, yakni Perkumpulan Keluarga Berencana Indonesia (PKBI) dan Ford Foundation. PKBI di dirikan pada tahun 1957 untuk mengatasi persoalan kependudukan pada masa itu, seperti tingkat kelahiran yang tinggi dan tingkat kematian ibu yang tinggi. Ford Foundation telah bermitra dengan PKBI sejak tahun 1960-an, bahkan sebelum 
berdirinya Badan Kependudukan dan Keluarga Berencana Nasional (BKKBN).

Pada saat rezim orde baru berkuasa, pemerintah menerima keberadaan PKBI, khususnya karena isu yang dianggkat adalah perempuan dan anak-anak/pemuda, sehingga dipandang sebagai isu yang'netral politik' oleh Rezim dan tidak mengancam rezim secara langsung, hal ini kemudian berlangsung sampai era 90 an dimana mayoritas arena operasional NGO atau LSM Lingkungan hidup masih dirasa sepi pemain local, baru sejak tahun 1998 pertumbuhan LSM-NGO boleh dikatakan menakjubkan. Dari hanya 3.000-an pada tahun 1985 menjadi sekitar 19.000 lembaga tahun 2001, dan sampai 2012 diperkirakan tiga kali libat dari data ini, dalam jumlah tersebut termasuk LSM atau NGO lingkungan Hidup di Provinsi Jambi, dan uniknya, LSM atau NGO lingkungan yang muncul dikemudian hari secara hubungan jaringan masih bisa dilacak ke NGO atau LSM pertama yang eksis di Provinsi Jambi, yaitu PKBI. Berikut Ilustrasi Evolusi NGO atau LSM yang ada di Jambi secara umum (LP3ES: 2001).

\section{Gambar 1:}

Evolusi Jaringan NGO atau LSM di Provinsi Jambi 1970-2018

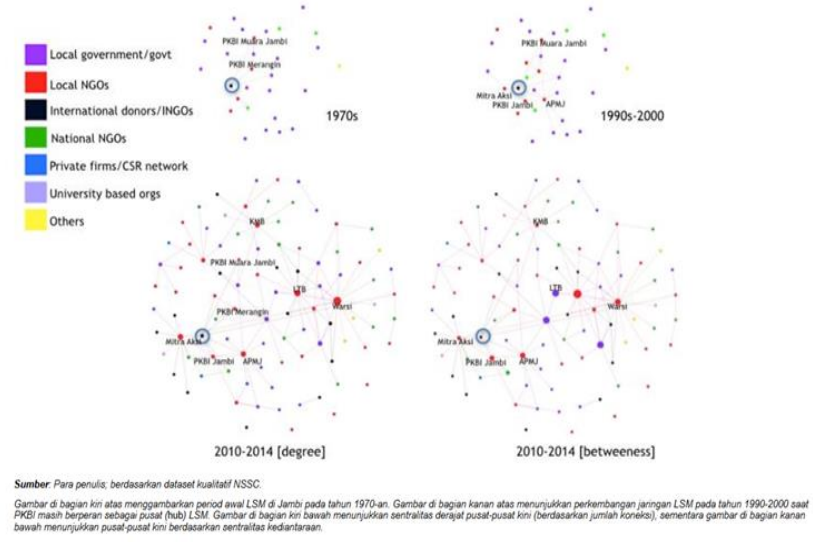

Badan Kesatuan Bangsa dan Politik (Kesbangpol) Provinsi Jambi pada 12 Agustus 2020 mencatat ada 1.108 organisasi masyarakat/LSM/ NGO di wilayah Provinsi Jambi, dengan ragam tujuan dan focus kegiatan yang berbeda-beda, data ini menunjukan secara tidak lagsung menunjukan situasi Demokratis yang mendorong masyarakat untuk menggunkan hak nya untuk ikut serta melakukan salah satu partisipasi politiknya yang diwujudkan dengan pembentukan organisasi organisasi kemasyarakatan yang banyak (Kesbangpol Provinsi Jambi).

Tabel 1:

Jumlah ORMAS/NGO/LSM di Provinsi Jambi 2020

\begin{tabular}{|l|l|l|c|}
\hline No & $\begin{array}{l}\text { Status } \\
\text { Ormas/NGO/LSM }\end{array}$ & Sumber Data & Jumlah \\
\hline 1 & $\begin{array}{l}\text { Ormas Tidak } \\
\text { Berbadan Hukum } \\
\text { dalam bentuk Surat } \\
\text { Keterangan } \\
\text { terdaftar }\end{array}$ & KesbangpolProvinsi & 338 \\
\hline 2 & $\begin{array}{l}\text { Ormas Tidak } \\
\text { Berbadan Hukum } \\
\text { dalam bentuk Surat } \\
\text { Keterangan } \\
\text { terdaftar }\end{array}$ & KesbangpolKabupaten/Kota & 642 \\
\hline 3 & $\begin{array}{l}\text { Yayasan dan } \\
\text { Perkumpulan }\end{array}$ & KEMENKUMHAM & 128 \\
\hline & Total & 1108 \\
\hline
\end{tabular}

Sumber: Data olahan Peneliti dari BPS Provinsi Jambi 2020.

Walaupun disisi lain, dari hal tersebut juga menyisakan tanya tentang kenapa semasif itu jumlah Ormas yang terdata di Pemerintah Provinsi Jambi. penelitian ini kemudian mengecilakan pengumpulan data tersebut untuk kemudian di fokuskan kepada data LSM atau NGO yang melakukan pendaftaran dan diakui oleh Institusi formal, peneliti melakukan seleksi data dengan lebih memfokuskan untuk mencari NGO atau LSM yang memang, di Provinsi ini sesuai dengan tema penelitian, sebagai ilustrasi tambahan guna memperkuat, adalah data sebaran yang didapatkan dari Bappeda Provinsi yang menggambarkan bagaimana LSM atau NGO LIngkungan Hidup di Jambi hampir ada disetiap wilayah Provinsi ini dengan ragam isu lingkungan yang lebih spesifik.

Gambar 2:

Peta Sebaran dan Wilayah Kerja NGO dan INGO di Provinsi Jambi

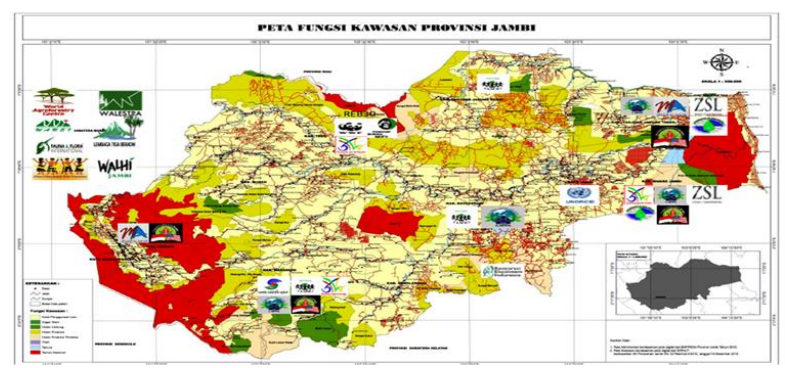

Selanjutnya, penelitian menyasar data Kesbangpol Kota Jambi, karena secara kasat mata beberapa kantor perwakilan resmi 
Lembaga-lembaga ini berada di Kota Jambi, walaup untuk daerah Operasional menyebar ke berbagai wilayah di Provinsi Jambi. Data Kesbangpol kota Jambi tercatat ada 46 Ormas maupun LSM yang terdata di Badan Kesatuan Bangsa dan Politik (Kesbangpol) Kota Jambi hasil pendataan tahun 2019. Dan kemudian jika data disempitkan menjadi, hanya menyasar NGO yang mempunyai concern terhadap Lingkungan Hidup di Provinsi Jambi, yang berkegiatan dan mempunyai miles stone aksi di 2-3 tahun terakhir maka jumlahnya akan Kembali mengecil, sampai laporan kemajuan ini dibuat muncul 13 Nama NGO Lingkungan hidup yang eksistensi kelembaagaan, kegiatan, serta rekam jejak nya terdokumentasi dengan baik.

Dibawah ini beberapa nama NGO Lingkungan Hidup di Provinsi Jambi:

1. Aliansi Konservasi Alam Raya Network (Akar Network): Visi: Fasilitasi anggota akar network dalam kegiatan advokasi TNKS guna mewujudkan interaksi yang harmonis antara manusia dengan lingkungan. Sedangkan Misinya: Akar network membangun kesadaran para pihak untuk mewujudkan hubungan yang harmonis antara manusia dengan lingkungan dikawasan taman nasional kerinci seblat.

2. Perkumpulan Gita Buana (Gita Buana): Visi: Terwujudnya masyarakat yang mampu mengelola sumber daya alam secara berkelanjutan dengan memperhatikan keseimbangan antara aspek ekonomi, sosial, budaya dan ekologi. Sedangkan Misinya: Mendorong terwujudnya masyarakat yang berdaya secara politik, hukum, ekonomi, sosial dan budaya melalui pengorganisasian masyarakat dan riset/study.

3. Perkumpulan Hijau (PH): Yang berlokasi di Jl. Dipati Unus, Pematang Sulur, Kec. Telanaipura, Kota Jambi 36361. JAMBI.

4. Setara Jambi (Setara): Visi Membangun masyarakat yang adil dan sejahtera yang menghargai hak-hak asasi manusia dan lingkungan. Sedangkan Misinya: Membangun kapasitas komunitas masyarakat lokal dalam pengelolaan sumber daya alam dengan mendorong mempengaruhi kebijakan serta melakukan pendidikan publik untuk pengelolaan sumber daya alam dan lingkungan hidup yang lestari, adil, berperspektif gender dan demokratis.

5. Sumatra Sustainable Support Pundi Sumatra (SSS Pundi Sumatra): Visinya: suatu masyarakat sipil yang terhubung satu dengan yang lainnya sehingga dapat saling membantu dan berbagi. Sedangkan misinya: Menyelesaikan Permasalahan: Kemiskinan, Kewirausahaan, Keruskan Kehutanan.

6. Wahana Lingkungan Hidup Jambi (Walhi Jambi): Visinya: Terwujudnya suatu tatanan sosial, ekonomi dan politik yang adil dan demokratis yang dapat menjamin hak-hak rakyat atas sumbersumber kehidupan dan lingkungan hidup yang sehat dan berkelanjutan. Sedangkan Misinya: Mengembangkan potensi kekuatan dan ketahanan rakyat, Mengembalikan mandat negara untuk menegakkan dan melindungi kedaulatan rakyat, Mendekonstruksikan tatanan ekonomi kapitalistik global yang menindas dan eksploitatif menuju arah ekonomi kerakyatan.

7. Wahana Pelestarian dan Advokasi Hutan Sumatera

(PerkumpulanWalestra): Visinya: Mendorong terwujudnya pengelolaan sumber daya alam yang berkelanjutan dan demokratis. Sedangkan misinya: Mendorong peran serta masyarakat dalam pengelolaan sumber daya alam dan lingkungan secara berkelanjutan dan berkeadilan, Mendorong lahirnya kebijakan sumber daya alam yang partisipatif, transparan, bertanggunggugat, berkeadilan dan demokratis demi terwujudnya pengelolaan sumber daya alam dan lingkungan secara berkelanjutan.

8. Yayasan Cappa (Cappa): Visinya: Melindungi Sumber Kehidupan Rakyat dan Mendorong Perubahan Tata Kelola Kehutanan dan Sumber Kekayaan Alam lebih Adil dan Demokratis. Bertempat di Jln. Kolonel Abunjani, Komplek 
Perumahan Puri Cemara Indah 1, Blok 1/04 RT.32 RW.04.

9. Yayasan KeadilanRakyat Jambi (YKR Jambi): Bertempat di Jln. Hibah Ibrahim no 28, Kotabaru Kota Jambi KOTA JAMBI - JAMBI, Fokusnya adalah Advokasi, Penelitian, investigasi, monitoring, Publikasi, dan Pelatihan.

10. Yayasan Mitra Aksi (YMA): Visinya: Bekerja Bersama Masyarakat meujudkan Ruang penghidupan dan kehidupan berkeadilan gender secara berkelanjutan, Fokusnya Pendampingan, bantuanteknis, penyuluhan, Advokasi, Penelitian, investigasi, monitoring, Pelatihan, dan Kerelawanan.

11. Yayasan Pinang Sebatang (Pinse): Visinya: Terwujudnya tatanan masyarakat yang demokrasi, berkeadilan, kesetaraan serta menjunjung tinggi HAM yang berdaulat secara hukum, politik sosekbud dan keseluruhan lingkungan hidupnya, sehingga mampu mengelola sumber daya alam secara berkelanjutan melalui kegiatan ekowisata. Sedangkan Misinya: Pengelolaan sumber daya alam secara berkelanjutan bersama dengan masyarakat untuk mandiri dan profesional dengan meningkatkan kemampuan organisasi melalui penguatan organisasi, peningkatan kerjasama lestari dan berkesinambungan serta menumbuh kembangkan perekonomian masyarakat.

12. KKI- WARSI: Bergerak dalam Bidangn Advokasi, Lingkungan hidup, Agraria Ekonomi, Pemberdayaan suku adat marginal, advokasi alam, pengelolaan gambut, Mitigasi, perubahan Iklim, ekonomi masyarakat sekitar hutan. Bertempat di Jl. Inu Kertapati No. 12, Pematang Sulur. Kecamatan Telanaipura, Kota Jambi. Provinsi Jambi, 36124

13. Institut Pemberdayaan Masyarakat (INSPERA): Visinya Mendukung terwujudnya pengelolaan sumberdaya alam secara adil dan berkelanjutan. Sedangkan misinya: Menghidupkan kembali potensi masyarakat untuk memperjuangkan akses dan control serta membangun kemandirian dalam pengelolaan sumber dayaalam, bertempat

di Jalan A. Thalib No. 71, RT. 12, PematangSulur, Telanaipura, Kota Jambi 36124, Indonesia.

Ketiga belas NGO lingkungan hidup ini, mempunyai rekam jejak dan aktifitas yang sangat sering bersinggungan dengan masyarakat dan permasalahan permasalahan terkait sumberdaya alam, hukum, kesejahteraan dan pemberdayaan, di beberapa aktifitasnya tidak jarang membuat mereka menjadi kelompok yang bersebrangan dengan beberapa kebijakan pemerintah, baik di tingkat Provinsi, Kabupaten dan kadang Nasional, mengingat Hutan adalah salah satu centre aktifitas lapangan mereka.

NGO yang disuguhkan di dalam tabel, adalah organisasi seperti kebanyakan NGO yang ada di Indonesia, yang untuk bisa terlibat langsung dalam politik Praktis, seperti yang umumnya dikenal oleh masyarakat, menjadi salah satu hal yang tidak mungkin dilakukan di Jambi maupun di Indonesia, berbagai aturan dan regulasi membuat hal tersebut tidak memungkinkan. jika mengacu kepada Undang-Undang Nomor 17 Tahun 2013 tentang Organisasi Kemasyarakatan, dibagian hal-hal yang dilarang untuk dilakukan ormas, Ormas dilarang mengumpulkan dana untuk partai politik (UU Ormas: Lihat Pasal 59 Ayat 2), Selain itu bahkan ormas yang didirikan oleh orang asing juga dilarang melakukan kegiatan politik. Yang dimaksud Undang-undang ini terkait dengan, kegiatan Politik, adalah kegiatan yang mengganggu stabilitas politik dalam negeri, penggalangan dana untuk jabatan politik, atau propaganda politik (UU Ormas: Pasal 52). Hal ini mengikat sebagai aturan dan berlaku kepada semua Ormas, termasuk NGO Lingkungan Hidup di Provinsi Jambi.

Sampai saat ini arena politik yang dijauhkan dari dari NGO Politik kekuasaan, merujuk kepada apa yang dikatakan Mukchtar Kusuma Atmadja, bahwa "hakikat kekuasaan adalah kemampuan seseorang untuk memaksakan kehendaknya atas pihak lain" (Kusumaatmaja: 1990), dan di negeri ini dan di era pasca reformasi, desentralisasi daerah masih menempatkan Partai Politik sebagai actor utama untuk hal ini, berkompetisi dalam sebuah arena politik 
untuk mencapai kekuasaan, dalam hal ini LSM atau NGO mempunyai arena yang seolah terpisah, apa yang di bicarakan sebagai sebuah arena politik adalah wilayah lain, dengan obyek yang masih sama. Arena Politik LSM atau NGO di Indonesia berbeda dengan yang dipunyai di negara lain, seperti Filipina misalnya, yang mempunyai agenda melakukan transformasi NGO atau LSM yang ada di sana menjadi partai politik pada tahun 2000. Agenda ini tentu tidak mungkin dilakukan di Indonesia, sebab undang-undang mengenai kepartaian (UU No. 3/1985) dan undang-undang keormasan (UU No. 8/1985) melarang organisasi politik mempunyai onderbouw Ormas atau LSM. Sebaliknya, Ormas atau LSM tidak dibenarkan berafiliasi dengan partai politik. Di Jerman, Belanda, Amerika Serikat, dan beberapa negara lain, selain terdapat LSM yang independen, masih terdapat LSM yang merupakan kepanjangan dari partai politik atau agama tertentu.

NGO atau LSM mau tidak mau harus diakui adalah pembawa perubahan sosial yang efektif, mengatasnamakan masyarakat marginal, ada pihak penyandang dana yang sebagian besar berasal dari pihak asing, dan menjalankan fungsi-fungsi menejerial organisasi dan program. Semua itu bersifat publik karena kepentingan masyarakat sangat melekat erat dan memiliki efek sosial, ada keterkaitan dengan mewakili dan membawa nilai-nilai yg termarginalkan secara social, termasuk terkait lingkungan hidup dan eksploitasi sumberdaya alam. Sebagai salah satu unsur masyarakat sipil yang terorganisir, LSM atau NGO di Jambi yang concern terhadap kelestarian lingkungan hidup pemberdayaan, menempati posisi paling banyak., kepedulian LSM tersebut adalah ungkapan dari sikap politik yang mengacu pada kesejahteraan masyarakat dan sedikit jauh dengan upaya menggalang kekuatan demi kekuasaan politik. Walaupun mau tidak mau hal ini kemudian akan menyebabkan LSM atau NGO tadi akan bersinggungan dengan arena politik local, seperti pemerintah Provinsi Jambi sebagai entitas politik kekuasaan terdekat.

Yang harus dipahami terlebih dahulu, dan nanti harus bisa dipaparkan dalam penelitian ini adalah sejauh mana peran LSM atau NGO Lingkungan hidup meMberikan pengaruh pengaruh politik sehingga ikut mempengaruhi pemerintah Provinsi Jambi dalam menghasilkan kebijakan-kebijakan terkait lingkungan hidup. Dari Ketiga belas NGO atau LSM lingkungan yang akan dijadikan informan primer, harus dipahami dulu Hal yang membedakan (dan harus dibedakan) antara sikap politik NGO atau LSM ini dengan partai politik di tingkat loka Provinsi Jambi adalah, ke tigabelas, NGO atau LSM melakukan kegiatan pemberdayaan dan pemihakan kepada masyarakat tanpa mengharapkan dukungan politik dan tidak sedang menggalang kekuatan politik. Sebaliknya, partai politik melakukan upaya penggalangan kekuatan politik. Sebagai ilustrasi, Ormas atau LSM dan partai atau organisasi politik sama-sama dapat mengadakan pelatihan pengembangan sumber daya manusia, membangun irigasi atau mendorong rakyat untuk membentuk koperasi simpan-pinjam dan lain-lain, tetapi harapan yang ingin dicapai masing-masing berbeda. Partai politik mengharapkan agar lewat upaya pemberdayaan dan kesejahteraan rakyat muncul dukungan bagi partainya pada saat pemilihan umum (pemilu). Sementara disisi lain, NGO sama sekali tidak mengharapkan dukungan dalam bentuk apa pun pada saat pemilu, karena keberadaan NGO secara langsung biasanya tidak berhubungan dengan pemilu, calon legislatif (caleg), dan sejenisnya. Meski demikian hal ini tidak langsung menghapus keadaan keadaan yang sering menempatkan dua entitas ini di posisi saling bersebrangan, langsung hilang, terutama di provinsi yang APBD nya sangat bergantung kepada hasil eksploitasi kekayaan alamnya.

\section{KESIMPULAN}

Berdasarkan pemaparan diatas terkait peran NGO atau LSM Lingkungan Hidup dalam Arena Politik Lokal Provinsi Jambi atau bagaima NGO atau LSM Lingkungan Hidup di Provinsi Jambi memainkan perannya sebagai salah satu Actor Civil Society (Pemeran dari Masyarakat Sipil) yang mempunyai kekuatan politik bukan untuk 
politik kekuasaan namun sesuai fungsinya dalam sebuah negara berdemokrasi. Keberadaan NGO atau LSM Lingkungan Hidup di Provinsi Jambi adalah salah satu yang ada di daerah dimana eksistensi NGO atau LSM Lingkungan hidup ini mempunyai lini masa yang cukup lengkap, sehingga dianggap bisa menggambarkan apa yang menjadi permasalah dari penelitian ini. Setelah melalui proses penelitian dan seleksi data pada prosesnya mengerucutkan menjadi 13 NGO atau LSM yang mempunyai konsentrasi pada lingkungan hidup yang ada di Provinsi Jambi. dimana ke 13 NGO atau LSM ini memiliki peran yang berbeda. Bagi peneliti ini masih memerlukan waktu yang panjang untuk bisa mengetahui apa yang menjadi peran dan pengaruhnya masingmasing dalam politik lokal Provinsi Jambi. Kesimpulan yang bisa diambil adalah keberadan NGO atau LSM di Provinsi mempunyai peran tersendiri sebagai mana fungsinya pada sebuah sistem demokrasi.

\section{DAFTAR PUSTAKA}

Afan Gaffar,(2006) Politik Indonesia: Transisi Menuju Demokrasi, Yogyakarta: Pustaka Pelajar.

Bagong Suyanto dan Sutinah,(2005) Metode Penelitian Sosial: Berbagai Alternatif Pendekatan, (Jakarta: Prenadamedia)

Blaikie P,Brookfield H.(1987).Land Degradation and Society. London (UK) : Matheuen.

Carter N. 2007. The Politics of Environment : Ideas, Activism and Policies. Cambridge (GB): Cambridge University Press

RL Bryant, Bailey S. (1997).Third World Political Ecology. London (UK) : Routlegde.

Diani M, Porta DD. (2006).Social Movement: An Introduction. Oxford (UK) : Blackwell Publishing.

Fakih M. 1996. Masyarakat Sipil untuk Transformasi Sosial: Pergolakan Ideologi di Dunia

ORNOP Indonesia. Yogyakarta (ID) : Pustaka Pelajar
Irwan Soehartono, (2011) Metode Penelitian Sosial : Suatu Teknik Penelitian Bidang

Kesejahteraan Sosial dan Ilmu Sosial Lainnya, (Bandunng: PT Remaja Rosdakarya),

Noer Fauzi Rachman. (2012).Interaksi Gerakan-gerakan Agraria dan Gerakan-gerakan Lingkungan di Indonesia Awal Abad XXI. Insist Press. Yogyakarta

Neil Carter (2012).The Politics of the Environment Ideas, Activism, Policy. University of York

Princen T, Finger M.(1994) Environmental NGOs in World Politics : Linking the Local and the Global. (New York (US) : Routledge)

Purwanto E. (2012). Nasionalisme Lingkungan: Pesan Konservasi Dari Lambusango. Aus Aid. Bogor.

Sugiyono, 2008. Metode Penelitian Bisnis: Pendekatan Kuantitatif, Kualitatif, dan R\&D.Bandung: Penerbit ALFABETA

Situmorang AW. (2013). Dinamika Protes Kolektif Lingkungan Hidup di Indonesia (1968-

2001).Yogyakarta: Pustaka Pelajar.

Singh, Rajendra. (2001) Social Movements, Old \& New: A Post-modernist Critique. New Delhi: Sagee Publications.

Thomas Princen, Matthias Finger (1994).Environmental NGOs in World Politics: Linking the Local and the Global. Routledge.

Civil Society Engagement Framework .Published by the Australian Agency for International

Development (AusAID), Canberra, June 2012., 34(1), 2011., 74-97.

Dharmawan, Arya Hadi (2005). Gerakan Sosial Lingkungan dan Perubahan Titik Berat

Kekuatan Politik Sipil Era Demokrasi. Bogor: Suplemen Matakuliah Ekologi Politik Pedesaan S3 pada Program Studi Sosiologi Pedesaan Sekolah Pascasarjana IPB. 
Fakih M, (2003). NGOs at the Crossroad, Bulletin SMERU Research Institute, No.08.

\section{Internet :}

http://cappa.or.id/index.php/welcome/detail/3 35

http://www.smeru.or.id/id/content/pangkalandata-ornop

https://tekno.tempo.co/read/1285796/wilayahhutan-di-jambi-tinggal-17-persenturun-20-000-ha-2tahun/full\&view=ok diakases 20 Juli 2020 